\title{
Enforcement of Environmental Law in the Field of Waste Management is in Accordance With the Principles of Good Governance in Kudus Regency
}

\author{
$1^{\text {st }}$ Trias Hernanda \\ Departement of Law, Universitas \\ Muhammadiyah Kudus \\ Kudus, Jawa Tengah, Indonesia \\ triashernanda@umkudus.ac.id
}

\author{
$2^{\text {nd }}$ Maslikan \\ Departement of Law, Universitas \\ Muhammadiyah Kudus \\ Kudus Jawa Tengah, Indonesia \\ maslikan@gmail.com
}

\author{
$3^{\text {rd }}$ Muhammad Ayub \\ Departement of Law, Universitas \\ Muhammadiyah Kudus \\ Kudus Jawa Tengah, Indonesia \\ muhammadayub@gmail.com
}

\begin{abstract}
- waste management is yet to be solved, in every area including Kudus. This research focuses on the obstacles dealt with in the process. The subject limitation area is Kudus. It is a research on doctrinal/normative law using statute approach. The data collected are library in nature, analyzed in a qualitative way. It shows that some laws are issued by the government in order to regulate waste management and the authority of local government. Included in these laws are Law no. 32 of 2009 on environmental protection and management. Law no. 18 of 2008 on Waste management, Law no. 24 of 2014 on Local government and regional regulation of Kudus on waste. Yet the awareness of the society seems to nullify the law and its implementation. There must be sanction for those breaking the law, in order to build Good Governance.
\end{abstract}

Keywords: waste management, good governance, law

\section{INTRODUCTION}

The population growth is increasing each year, Indonesia ranks fourth in the world with a total of 269.1 million people, one rank below the United States of america with a total of 328.7 million people. On the other side the economy is also on the rise, marked by the growing number of development in the industrial sector. Kudus regency is a regency that has many industries, one of which is the cigarette industry that grows in the kudus regency.

Industrial and population growth usually has effects on the environment, such as air pollution, garbage, environmental pollution and noise pollution. One of the environmental problems faced in the Kudus regency is the problem of rubbish, the phenomenon is characterized by the Kudus regency government which requires additional land to collect the rubbish.[1] and the amount of rubbish dumped in the Kudus regency rivers.

The main actor in environmental issues is humans, in managing the required waste and carrying capacity for those who support the waste sector, according to Koesnadi Hardjasoemantri[2], humans are part of the ecosystem, namely as the manager of the system. Environmental damage is a side effect of human actions to achieve a goal. Low legal awareness and culture that drives people to shift the rules that apply. Low legal awareness is characterized by the lack of compliance with the rules governing waste, the role of legal awareness in society has the aim of
A legal umbrella in the management of waste has been regulated in Law Number 18,2008 concerning Waste Management, the purpose of this law is to improve public health with environmental quality and to make waste a resource. In addition to the Waste Management Act, there are several regulations that can be used as references $n$ waste management arrangements such as Law Number 18,2008

Law Number 23 of 2014 concerning Regional Government and Regional Regulation of Kudus Regency Number 4 of 2017 concerning Waste Management. From some of the rules in it there are sanctions that can be applied to individuals or industries that violate waste, but seeing the real situation such as the amount of garbage in rivers means that it can be said that the sanctions can not provide a deterrent effect. for those who violate. So that the optimization of sanctions from the regulation must be assessed and also the role of the government is very important in carrying out waste management and environmental law enforcement in the regions in accordance with the principles of good governance.

Law Number 23 of 2014 concerning Regional Government and Regional Regulation of Kudus Regency Number 4 of 2017 concerning Waste Management. From some of the rules in it there are sanctions that can be applied to individuals or industries that violate waste, but seeing the real situation such as the amount of garbage in rivers means that it can be said that the sanctions can not provide a deterrent effect. for those who violate. So that the optimization of sanctions from the regulation must be assessed and also the role of the government is very important in carrying out waste management and environmental law enforcement in the regions in accordance with the principles of good governance.

\section{METHOD}

This research is a normative or doctrinal research in normative law related to written norms, which are made and promulgated by institutions or officials involved and discuss the law as a normative system that is autonomous, independent, closed and accessible to real people[3]. and the type of data used in secondary data are legal books including theses, theses, legal dissertations and legal journals[4]. The type of approach used by researchers is the type of approach 
to the statute (statute approach) in research legislation researchers must understand the hierarchy, the principles in the legislation[5]. This research will make environmental law enforcement in the field of waste management in the Kudus Regency as a model.

\section{RESULT}

\section{A. Rubbish and their Problem}

According to the big Indonesian dictionary, rubbish is goods that are discarded or no longer used, whereas according to Law Number 18 Year 2008 regarding Waste Management, rubbish is the rest of human daily activities. Waste management is a very complex problem in almost every urban area that has problems about waste and its management. HR Sudrajat gives an explanation about rubbish, rubbish is a very important problem, especially problem in urban areas. HR Sudrajat explains:

a. The volume of waste is very large, exceeding the capacity of temporary shelters (TPS) and final processing facilities.

b. The landfill (TPA) is increasingly eroded by other objectives.

c. Waste that has not been cooked or composted is not removed from the final processing site

d. Management of waste management that is not effective.

e. Waste management is felt to have no positive impact on the environment.

f. Lack of government policy support.

In January 2019, based on news from detik.com, villagers complained about the garbage that pill up under the kastono bridge in Kesambi village, Mejobo, Kudus Regency, villagers are worried that the piles of garbage in the river will cause levees to burst and flood[6]. as well as the appearance of garbage under the bridge of Ploso Village, Kudus Regency, can be seen every day. One of the rubbish that is dangerous because it cannot be recycled is rubbish that comes from a plastic base material.

Dependence of people on plastic bags is still a lot, because it's cheap and the ingredients are durable. Untoro Budi Surono and Ismanto explained that plastic has advantages over other materials including strong, lightweight, flexible, rust resistant, not easily broken, easily colored, easily formed, and good heat and electricity insulators, but plastic that has become a waste will negative impact on the environment because it is not easy to degrade[7]

Community behavior is one of the factors driving increased complexity in waste management, lack of awareness and lifestyle of some people who tend to be less in favor of order and compliance with existing rules. However, the purpose of making rules is for the common good, not the interests of a group. Mochtar Kusumaatmadja explained that the law can function as a driving force for development, that is, to be able to bring the community forward[8]. Based on Mochtar Kusumaatmadja's opinion, the rule of law makes people think about the future not just for a moment and directs the community to change the pattern of conversation.

\section{B. Rules of Waste Management in Kudus Regency}

Law Number 18 Year 2008 concerning Waste Management provides an understanding of waste management as a comprehensive, comprehensive and sustainable activity that is complete and sustainable which includes reduction and handling of waste while understanding waste according to Sulistyorini is part of something that is not used, not liked or something that must be discarded, which generally comes from activities carried out by humans (including industrial activities), but not biological (due to human waste not included) and generally solid[9].

Waste becomes a problem from year to year, the nature of waste which is the final remnants of goods that are not used and must be disposed of, so with the increase in the number of people who are not controlled then the impact also increases the resulting waste. Waste management is a shared responsibility between the central government and regional governments. The rules governing waste management are clear and stated in the Act or rules which are at the level below the law such as regional regulations:

\section{Law Number 32 of 2009 on The Protection and Environmental Management (UUPLH)}

Every citizen has the right to guarantee good and healthy environmental protection, the guarantee is contained in Article 2 of Law Number 32 of 2009 concerning protection Environmental Management (UUPLH), environmental protection and management Based on the principles contained in article 2 of the UUPLH It can be said that all UUPLH principles have a general relationship in waste management. Likewise, with waste management in the district area, in addition to article 2 of the UUPLH there are also other articles, namely article 63 of the UUPLH concerning the duties and authorities of the government and regional government.

3. Law Number 18 of 2008 On Waste Management.

The waste management law was born based on the considerations written in Law Number 18 regarding waste management, including the increase in population and changes in community consumption patterns resulting in increasing volume, types and characteristics of waste which are very diverse and garbage has become a national problem so its management needs to be carried out comprehensively and integrated from upstream to downstream in order to provide economic benefits, be healthy for the community, be safe for the environment and be able to change people's behavior.

The articles in Law Number 18 of 2008 discuss waste management, in article 5, article 6 and article 9 the substance of the article discusses the role of the central and regional governments in waste management, while the contents of the following article 9 are followed:

1) Establish waste management policies and strategies based on national and provincial policies.

2) Carry out district / city scale waste management policies in accordance with norms, standards, procedures and criteria set by the government.

3) Supervise and foster the performance of waste management carried out by other parties 
4) Establish temporary storage sites, integrated waste management sites, or final processing sites.

5) Monitoring and evaluating periodically every 6 months for 20 years for the final waste disposal facility with an open disposal system.

6) Develop and regulate emergency response systems for waste management in accordance with their authority.

Article 12 discusses the obligation of each person in the management of household and similar household waste must reduce and handle waste in an environmentally sound manner. The substance of Article 12 can be interpreted that every person is obliged to manage waste and its processing so as not to disturb other ecosystems, so that it can protect from natural damage that results in disaster.

\section{Law Number 23 of 2014 On Local Goverment}

The Local Government Law has been amended five times, starting from the first issuance of the Regional Government Act of 1957 to the latest amendment to Law Number 23 of 2014, but the spirit of the principle of decentralization or delegation of authority of the regional government has the right to take care of its regional affairs itself, starting when the amendment of Law Number 5 of 1974 is replaced by Law Number 32 of 1999. Law Number 23 of 2014 also regulates environmental affairs, namely contained in article 12 concerning compulsory governmental affairs which are not related to basic services.

The granting of freedom in managing their own regions or better known as regional autonomy is directed to accelerate the development and welfare of the people through community involvement and empowerment, including in the management of waste, the local government has the right to regulate waste management in their respective areas so that they can realize Good Govenance with public support

\section{E. Regional Regulation Kudus Regency Number 4 of 2017 on Waste Management}

Establishment of Regional Regulation No. 4 of 2017 concerning Waste Management in Kudus Regency aims to reduce the potential for environmental pollution due to waste as written in the regional regulation's explanation. The increase in population due to the development of Kudus Regency which is increasingly dense has negative effects, one of which is the negative effect tends to increase the volume of waste produced, if the volume of waste that is increasingly rising and not managed properly and correctly then the garbage will pile up everywhere.

Article 4 contained in Regional Regulation No. 4 of 2017 regulates the objectives of waste management in Kudus regency aimed at improving public health and environmental quality and making waste a resource. This regional regulation also regulates waste management at the household level, which is contained in Article 16, which regulates the management of household and similar household waste, consisting of. Firstly Reduction of waste, secondly Waste handling. Regional Regulation No. 4 of 2017 also includes administrative sanctions in Article 49 and criminal sanctions in Article 51.

\section{F. Enforcement of Environmental Law in the Field of Waste Management in Accordance with Good Governance Principles.}

Law enforcement aims to change and make people aware of their actions, according to Suharto, quoted by $\mathrm{R}$ Abdussalam, said that law enforcement is a series of activities carried out by law enforcement officials both preventive measures and actions in applying applicable legal provisions in order to create a safe and orderly atmosphere[10]

Sudarto gives the definition that law enforcement is attention and cultivation, both acts that are against the law that actually happened (onrecht in actu). or illegal acts that might occur (onrecht in potentie)[11] other than that the understanding of environmental law enforcement is an effort to achieve compliance with regulations and requirements in the provisions of applicable law in general and individually, through supervision and application in administrative, civil and criminal penal[12]

The application of a law specifically dealing with waste followed by the Regional Regulation on Kudus regency waste is felt not to be effective enough to reach all communities, only some are familiar with the rules containing sanctions, as evidenced by several rivers that become landfills, and recently a Kudus regency community was caught in a justisi operation by the municipal police for littering.

Enforcement of environmental law in the field of waste management requires a synergy in upholding the law, namely between the community, government and law enforcement officials so as to realize an orderly dynamics of environmental law. According to Elizabeth "in being so environmental law engages all the institutional law and legal resources of constitutional democracy to operate - public discourse, expertise, public administration, legislation, accountability dispute resolution, multi-level governance and much else besides[13]" Kudus District Government in realizing the principle of regional autonomy, has formed a special regulation that specifically discusses and enforces environmental law in the field of waste.

Law enforcement with a preventive approach when applied to environmental law in the field of waste management is more appropriate, because law enforcement is preventive more to prevent and anticipate by building public awareness and obedience so that the culture in society will change slightly, as Brian $\mathbf{J}$ Peterson argues in his Environmental Journal Problems threaten our way of life. Recognizing and responding to and these problems is essential, but requires transforming our society and culture[14]

An example is the Tunjung Seto waste bank in Bae Subdistrict Village, Kudus Regency. The initial formation of this garbage bank was due to concerns over littering and minimal waste bins, the pattern of the Tunjung Seto waste bank is requiring every citizen to deposit their waste in the waste bank, then the members of this garbage group classify 
the rubbish and bai two types of pots that can be used as handicrafts or rubbish for sale[15].

Kudus regency Government itself has actually tried to make various efforts in managing waste by encouraging each village to create a garbage bank and working together with the private sector to foster a sense of waste management awareness, as was done with PT Nojorono in conducting training to strengthen waste management and banks rubbish.

Good waste management is basically an embodiment of efforts to create a government based on the principles of good governance, linkages between the principles of good governance with waste management among others legal certainty, balance, fairness and fairness in responding to the arising and principles of public interest[16]

Regional Regulation No. 4 of 2017 concerning waste management in Kudus regency also contains legal certainty, balance and fairness. Articles containing good governance principles in the regional regulation are in article 3, article 36 and article 42 which are in line with the principle of good governance and legal rules, article 5 is in line with the principle of orientation, article 39 is in line with community participation and Article 43 Dispute resolution is in line with the principle of responsiveness.

Basically, if the implementation of good governance is carried out well based on its principles, the enforcement of environmental law in waste management will be carried out effectively in other words, the enforcement of environmental law in the field of good waste is very determined and influenced by good governance.

\section{CONCLUSION}

Regulations on waste management in Kudus regency are already in line with higher regulations, waste management in Kudus regency has been regulated in regional regulation No. 4 of 2017 where the regional regulation is already in consideration of the above rules such as Law No. 18/2008 on waste management, plus strengthening in the environmental sector which is considerate with Law Number 32 Year 2009 concerning environmental protection and management and is related to law number 23 of 2014 concerning regional government in the context of organizing regional autonomy which can create regulations for waste management.

Enforcement of environmental law in terms of waste management in the holy district through two approaches, namely preventive and repressive. These two approaches are considered to be able to increase awareness in the community and also the approach is in line with the principles of good governance by involving the community in waste management.

\section{ACKNOWLEDGMENT}

I would like to express my special thanks of gratitude to my rector (Rusnoto, SKM .,M.Kes (Epid) as well as my friend lecture at Muhammadiyah University of Kudus (Janu Arlinwibowo and Yunus Mustaqim). Secondly i would also like to thanks my parents and my wife who helped me alot finalizing this project within limited frame.

\section{REFERENCES}

[1] Akhmad Nazarudin, "Pemkab Kudus butuh lahan tambahan untuk menampung sampah masyarakat," 2019. [Online]. Available: https://www.antaranews.com/berita/941493/pemkab-kudus-butuhlahan-tambahan-untuk-menampung-sampah-masyarakat.

[2] Koesnadi Hardjasoemantri, Hukum Tata Lingkungan, 8th ed. Yogyakarta: Gadjah Mada University, 2012.

[3] Peter Mahmud Marzuki, Penelitian Hukum. Jakarta: Kencana Prenida Media Grup, 2011.

[4] P. M. Marzuki, Penelitian Hukum. Jakarta, 2011.

[5] P. M. Marzuki, Penelitian Hukum. Jakarta: Kencana Prenida Media Grup, 2011.

[6] A. Hazami, "Ngeri! Penampakan Sampah Menutupi Badan Sungai di Kudus," 2019. [Online]. Available: https://news.detik.com/beritajawa-tengah/d-4388576/ngeri-penampakan-sampah-menutupi-badansungai-di-kudus. [Accessed: 09-Nov-2019].

[7] U. B. Surono and Ismanto, "Pengolahan Sampah Plastik Jenis PP, PET dan PE Menjadi Bahan Bakar Minyak dan Karakteristiknya," J. Mek. dan Sist. Termal, vol. 1, no. 1, pp. 32-37, 2016.

[8] Mochtar Kusumaatmadja, Fungsi dan Perkembangan Hukum Dalam Pembangunan Nasional. Bandung: Bina Cipta.

[9] N. R. S. Sulistiyorini, R. S. Darwis, and A. S. Gutama, "Partisipasi Masyarakat Dalam Pengelolaan Sampah Di Lingkungan Margaluyu Kelurahan Cicurug," Pros. Penelit. dan Pengabdi. Kpd. Masy., vol. 3, no. 3, p. 414, 2016.

[10] R. Abdussalam, Penegakan Hukum di Lapangan oleh polri. Jakarta: Gagas Mitra Catur Gemilang, 1997.

[11] Sudarto, Kapita Selekta Hukum Pidana. Bandung: Alumni, 1986

[12] Syahrul Machmud, Penegakan Hukum Lingkungan, 1st ed. Yogyakarta: Graha Ilmu, 2012.

[13] E. Fisher, "Unearthing the Relationship Between Environmental Law and Populism," J. Environ. Law, no. October, pp. 383-387, 2019.

[14] B. J. Preston, "The End of Enlightened Environmental Law?," J. Environ. Law, no. October, pp. 399-411, 2019.

[15] L. Yakub, Ma'ruf, nikmah, Ovi, safina, "Kreasi Karang Taruna Tanjung Seto Olah Sampah Yang Terbuang Menjadi Uan,” 2019. [Online]. Available: https://radarkudus.jawapos.com/read/2019/03/05/123089/yangterbuang-menjadi-uang. [Accessed: 16-Sep-2019]

[16] Hyronimus Rhiti, kompleksitas Permasalahan Lingkungan Hidup. Yogyakarta: Universitas Atma Jaya, 2005. 